Miroslav Pohanka, Dr.

\title{
Colorimetric hand-held sensors and biosensors with a small digital camera as signal recorder, a review
}

https://doi.org/10.1515/revac-2020-0111

Received February 10, 2020; accepted May 28, 2020

\begin{abstract}
Sensors, biosensors, lateral flow immunoassays, portable thin-layer chromatography and similar devices for hand-held assay are tools suitable for field or out of laboratories assays of various analytes. The assays frequently exert a limit of detection and sensitivity close to more expensive and elaborative analytical methods. In recent years, huge progress has been made in the field of optical instruments where digital cameras or light sensitive chips serve for the measurement of color density. General availability of cameras, a decrease of prices and their integration into wide spectrum phones, tablets and computers give the promise of easy application of analytical methods where such cameras will be employed. This review summarizes research on hand-held assays where small cameras like the ones integrated into smartphones are used. Discussion about such assays, their practical applicability and relevant specifications are also written here.
\end{abstract}

Key words: Bioassay; Biosensor; Color Density; Colorimetry; Digital camera; Hand-Held Assay; Image processing; Immunosensor; Lateral Flow Immunoassay; Thin-Layer Chromatography.

\section{Introduction}

Currently, gas chromatography, liquid chromatography and high performance liquid chromatography are standard separation analytical methods that can be further combined with simple physical detectors

\footnotetext{
*Corresponding author: Miroslav Pohanka, Faculty of Military Health Sciences, University of Defense, Trebesska 1575, Hradec Kralove CZ-50001, Czech Republic

E-Mail: miroslav.pohanka@gmail.com
}

(voltammetric, fluorimetric) or mass spectrometry and these methods have applicability for the measurement of a wide number of analytes, from simple inorganic or organic compounds to sized macromolecules of biological origin [1-10]. These methods represent direct competition or etalon for any newly developed assay. In the field of genetic material identification, polymerase chain reaction is the method of first choice, it can be performed for the identification of microorganisms, diagnosis of diseases, forensic search of perpetrators or victims, surveillance on genetically modified organisms, food control and others [11-18]. A lot of analytes can be determined by immunoassays. There are conditions where an antibody specific to the analyte should be available when the analyte is measured or there should be a specific antigen when antibodies are examined as a marker. Standard enzyme-linked immunosorbent assay (ELISA) and radioimmunoassay are examplesof the most common ones [19-25]. The aforementioned analytical methods are routinely available in hospitals, food and hygienic control, industrial and similar laboratories. Though there are of course other methods and devices, the mentioned standard analytical methods are seen as the main tool in the current analytical praxis.

This review is focused on the recent progress on hand-held assays like sensors, biosensors, lateral flow immunoassays, portable thin-layer chromatography and similar devices using small digital camera for output signal measurement. Tiny digital cameras like the one integrated in smartphones or portable touristic camera devices were considered here because they are cheap and suitable for everyday carrying. Analytical protocols can be of course based on highly sensitive photographic devices but these are out of scope of this paper. The hand-held assays are not direct competitors to the aforementioned standard analytical methods but they can support their findings, verify them, and they can also work in field and harsh conditions and represent a cheap and easy to perform type of assay. This review summarizes the recent findings on the issue 
of hand-held assays with digital camera as the output. Discussion about the practical role of hand-held assays, their differences and advantages, and their respective disadvantages to the standard methods are written here as well. The expected direction of the next research in this field is extrapolated from the knowledge of the current literature.

\section{Color density and its measurement}

Measurement of fluorescence and spectral absorbance are the most common methods and both of them are typically performed in cuvettes, microplates, flow through cells and so on. Compared to the standard methods, the assays presented in this review use standard digital camera for the outputting signal measuring. A standard digital camera is a device for making photographs and it is composed from common parts including optics (camera lens), the lens aperture, image sensor, shutter and image sensor. There are other optional parts like the control screen, viewfinder and camera flash for the support of taking pictures in less illuminated spaces. Just the flash is an important optional part when the camera is intended as part of a hand-held assay because the source of light is necessary to make the results repeatable and reproducible [26].

The most common digital output from a camera is jpeg (respectively its variants like jpg, jpe, jif, etc.) format. The jpeg contains 8 bit color information though some specific devices are able to produce jpegs with a higher value of information. The color information is kept in RGB color model which means that every pixel of the photograph contains information about Red (R), Green $(G)$ and Blue (B) color channels [27]. The final color is achieved by the mixing of the three mentioned color channels. The 8 bit point to color depth is a discontinuous variable. The color depth is calculated as $2^{\mathrm{n}}$ where $n$ letter is an information about number of bits. For an 8 bit photograph, it has value $2^{8}$ which is equal to $256[28,29]$. It means that the color depth can have one of the 256 values equal to a number from 0 to 255. Every pixel of a photograph contains three numbers, one for the $\mathrm{R}$ channel, one for $\mathrm{G}$ and one for $\mathrm{B}$. Compared to the standard 8 bit photograph, a photograph with only two bits contains four number for each channel, while a 12 bit photograph contains overall 4,096 color shades and 14 bit 16,384 color shades. 8 bit photography is typical for small and cheaper cameras with jpeg as its output. More expensive cameras can provide noncompressed raw data (typically 16 bit for digital single- lens reflex cameras) or non-compressed pictures in formats like tiff. Tiff format has ability to keep a high value of color depth. The so-called true color pictures and movies have color depth 24 bit corresponding with $16,777,216$ values. Low value of color depth can represent a problem when a sample containing an analyte in concentration slightly above limit of detection should be distinguished from controls. Currently, 8 bit jpeg format is the most typical so any hand-held analytical method established on the standard camera devices integrated into phones, tablets or computers should consider this limitation when economic competitivity is a followed parameter. The general principle of digital photography and the shortcomings in its methodology were extensively reviewed in work by Pohanka, 2017 [26]. The idea of digital image processing was also extensively discussed in the cited papers [30-33]. Cameras can suffer from various problems with image quality. Apart from mistakes in assembly or construction shortcomings, there are also problems determined by the physical principle of photography: optical aberrations caused by lenses or noise and other negative impacts caused by detector chips. Cheaper cameras like the integrated one in other smart devices can suppress the aberrations and noise by software resulting in a partial correction but also in data loss. Collecting photographs in a raw format and not in standard picture format like jpeg is one way on how to avoid this effect. On the other hand, cheaper cameras do not support the collection of raw digital data from camera chip. When looking at specific shortcomings, the following can be considered: lenses can suffer from distortion (pincushion or barrel distortion), resulting in the whole image deformation. Edge parts of a picture can suffer from various chromatic aberrations appearing like colored lines. The edge parts of a picture can also darken due to the vignetting effect. The aforementioned effects can be suppressed by the option of a higher aperture number when the light conditions allow this. A negative impact on picture quality can also be due to conditions on the chip caused by light intensity and coloration in the moment of picture taking. Insufficient intensity of light leads to the setting of a higher ISO value but a higher ISO causes significant noise in the picture or camera record. There can also be problems with white balance resulting in incorrect color temperature on the recorded picture or camera record. A reliable source of light such as an integrated light diode or flash is necessary for avoiding problems with ISO and white balance. The white balance can also be switched off on most of devices which is desired in an analysis. The principle of information kept in a photograph is also explained in figure 1. 


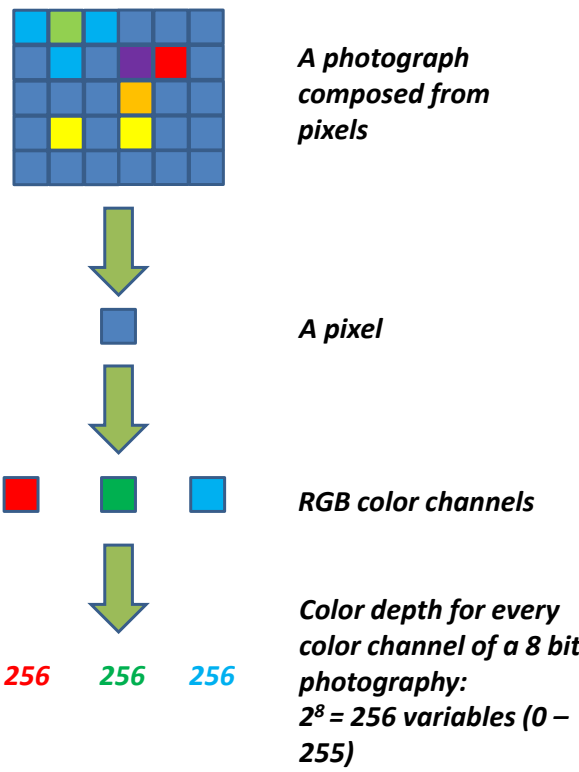

Figure 1 Explanation of digital information kept in an 8 bit photograph.

Digital pictures are a source of data for further analysis by many methods. The hand-held ones are discussed in the next chapters, but there are of course other ways to employ digital photography. Image processing has broad applicability in analysis of specific compound, chemical, physical and other processes or diagnosis of diseases. Such an application is of course set to specific conditions of the assay purpose. Characterization of skin structures [34, 35], glaucoma diagnosis [36, 37], study of cells in neuronal cultures [38], control of diamond's optical properties [39], pathological examinations [40], characterization of diffusing fluorescent molecules [41], classification of wheat grains and detection of poste damaged grain [42, 43], quantum steganography [44], improved microscopy and other typically biologist techniques [45-49], automated and robot self-controlled processed within Industry 4.0 strategy [50], fruit and vegetable quality control [51], biochemical analysis [52] and temperature distribution [53] are all methods linked to image processing. The digital camera can of course be linked to a bioassay such as in the following text: The bioassay can be based on various principles where an enzymatic or another chemical reaction provides a colored product or affinity interaction causing the catching of a fluorescent or colored trace. The general principle of a bioassay with digital camera as the output is depicted in figure 2 . This review is focused on colorimetry and just the colorimetry is taken for an optimal method in connection of a small camera. The cameras can also be integrated into fluorimetry but there are higher demands on technical equipment, optical filters and light sources. There are known applications of fluorimetry using a digital camera and these techniques can be performed for example for oil droplets analysis [54], fluorimetry of eye applicable for diagnostics in ophthalmology [55], and DNA hybridization measurement $[56,57]$.

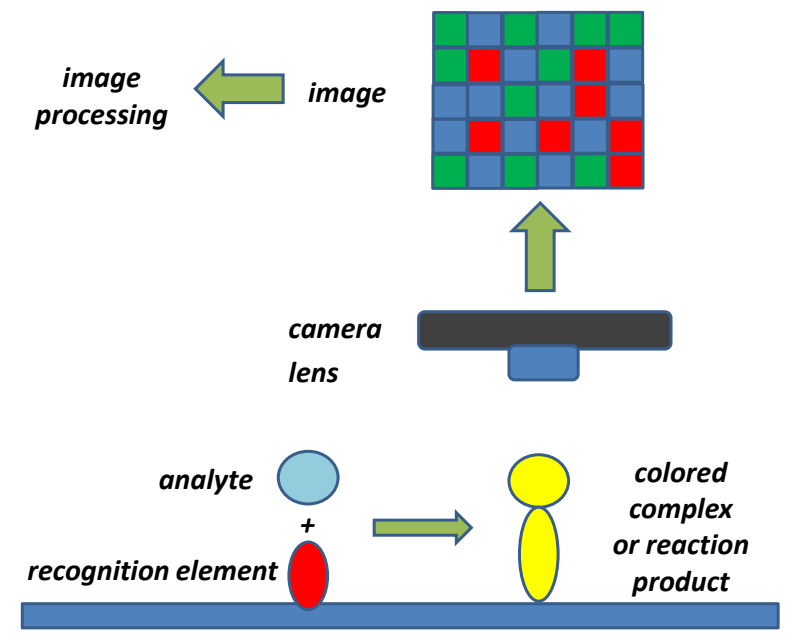

Figure 2 General principle of a bioassay with digital camera as the output.

\section{Colorimetric biosensors with thin surfaces or small volumes and Thin- Layer Chromatography}

A thin layer where coloration is formed due to an increase in the concentration of chromogenic analyte is common in thin layer chromatography. Thin layer chromatography can be easily linked with digital photography and illumination by UV light and this is optimal for this purpose. For instance, Tie-xin and Hong performed thin layer chromatography for cichoric acid from a plant Echinacea purpurea [58]. The authors used UV light and images recorded by a digital camera. The assay exerted a limit of detection of $0.067 \mu \mathrm{g}$ and the calibration plot had quite good linearity and a coefficient of determination equal to 0.9917. In the mentioned study, a standard digital camera with a resolution of 5 megapixels and $10 \times$ optical zoom (no further specifications were provided in the paper) was used. Thin layer chromatography with a digital camera as the output was also tested by Simon and coworkers for an investigation of natural extracts [59]. The researchers extracted yellow bedstraw Galium verum into alcohol and made the principal component analysis, including the performance of thin layer chromatography, and recorded photographs under UV light with a wavelength of 254 and $366 \mathrm{~nm}$. A singlelens reflex camera Nikon D3100 (Nikon, Tokyo, Japan) 
with a standard Advanced photo System type-C (APS-C) sized Complementary Metal-Oxide Semiconductor (CMOS) chip was the digital data recording device. As a result, the authors described a specific chromatograph serving as fingerprints for the extracts. Thin layer chromatography with a digital camera as the output was found to be a reliable tool for various analytes and assays of amino acids after ninhydrin modification [60], creatinine labelled by iodine [61], leucine and isoleucine [62], amphetamine-like amines [63], and polycyclic aromatic hydrocarbons [64].

Thin layer can serve as a platform for enzymatic reactions, therefore it can be simply combined with color depth measurement by a digital camera. Such a concept was adapted for assays of butyrylcholinesterase as a biochemical marker in blood plasma and serum where it can help to reveal some types of poisonings or liver malfunctions [65]. The cited assay was based on color changes where indoxylacetate was converted by the enzyme butyrylcholinesterase to blue colored indigo and the whole assay was performed on small cuts of filter paper. Color depth was recognized from photographs taken by a camera integrated into a smartphone Samsung Galaxy S5 (Samsung, Seoul, Korea). The best sensitivity exerted the assay in $\mathrm{R}$ channel for which the limit of detection was equal to $3.09 \times 10^{-6} \mathrm{~kat} / \mathrm{ml}$ while $\mathrm{B}$ channel had a limit of detection of $4.67 \times 10^{-6} \mathrm{~kat} / \mathrm{ml}$ and $\mathrm{G}$ channel $4.36 \times 10^{-6} \mathrm{~kat} /$ $\mathrm{ml}$. The analytical parameters received in this study were quite close to standard spectrophotometry. An unpublished part of the experiment from the cited paper containing calibration of diluted serum is depicted as figure 3.

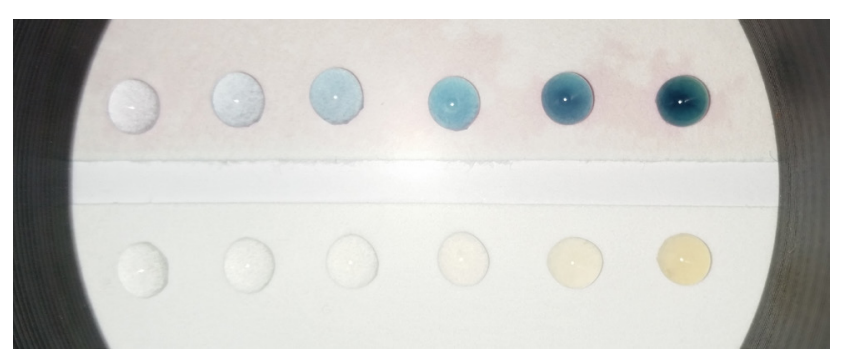

Figure 3 Measurement of plasma samples containing active butyrylcholinesterase. The photograph is an unpublished part of cited experiment [65] . The upper line contains saline solution diluted plasma samples and paper containing indoxylacetate, the lower part contains the same samples on a clean cut of paper. The photograph was taken by a smartphone camera and served for color depth determination when the photograph underwent image processing.

A low space of bubble wrap was selected in a study to establish a colorimetric method for measurement of glucose level [66]. The bubbles were filled with sol-gel, glucose oxidase, peroxidase and o-phenylenediamine dichloride as a chromogenic substrate. When added to a sample containing glucose, a cascade of reactions were initiated by the two immobilized enzymes and orangebrown end product from o-phenylenediamine was formed and photographed by a camera integrated into a smartphone Sony Xperia MT27i (Sony, Tokyo, Japan). The assay exerted a limit of detection of $0.75 \mathrm{mmol} / \mathrm{l}$ which is under the physiological level of glycemia (in health people $3.9-11.1 \mathrm{mmol} / \mathrm{l}$ ) therefore the functionality of the method was reached. The assay fully correlated with standard spectrophotometry though the sensitivity was a little lower. A colorimetric assay working with small volume of analyte developed Marinho and coworkers for the determination of ethanol content in beverages [67]. They chose a smartphone camera as an analytical device and microtubes as a measuring cuvette. The coloration was formed by the addition of phenolphthalein in an alkaline medium into an alcohol beverage sample. The assay had a limit of detection $2.1 \%(\mathrm{v} / \mathrm{v})$ ethanol which is quite a high number, on the other hand it is enough to measure alcoholic beverages since the content of ethanol in them is significantly higher [68, 69]. A smartphone digital camera (Samsung Galaxy S5 by Samsung) served as a measuring device for the detection of neurotoxic carbofuran and consisted of cuts of filter paper with immobilized homogenate from psychrophilic bacteria [70]. The assay was based on a lipase mediated conversion of indoxylacetate to blue indigo, which was stopped by an irreversible enzyme inhibition in the presence of carbofuran. The limit of detection was equal to $3.72 \times 10^{-8} \mathrm{~mol} / \mathrm{l}$ for a $5 \mu \mathrm{l}$ sized sample. A survey of mentioned methods is given in table 1 .

\section{Thin layer stational immunoas- says and Lateral Flow Immunoassays}

The recognition ability of antibodies is a principle of the immune response to an invading pathogen. The fact that antibodies are highly selective proteins can be used for various assays where an antigen is detected. The assay of prostate-specific antigen [71], infectious diseases [7274], antibiotics [75], and food allergens [76] are relevant examples. The assay can also work in an opposing manner when the bioassay contains an antigen as a reagent or immobilized part and antibody is measured as an analyte. Immunosensors for celiac disease based on the detection of anti-transglutaminase antibodies [77] and detection of antibodies against infectious pathogens like Francisella tularensis [78] can be exampled.

Immunosensors with a digital output work on a similar principle like the other immunoassays except for the signal measuring technique. The relevance of immunosensors 
Table 1 Thin layer methods with digital camera on the output

\begin{tabular}{|c|c|c|c|c|}
\hline Assay method & Used camera & Analyte & $\begin{array}{l}\text { Limit of detection respec- } \\
\text { tive further specifications }\end{array}$ & References \\
\hline thin layer chromatography & $\begin{array}{l}\text { an unspecified camera } \\
\text { with } 5 \text { megapixels and } \\
\text { 10x optical zoom }\end{array}$ & $\begin{array}{l}\text { cichoric acid from } \\
\text { a plant Echinacea } \\
\text { purpurea }\end{array}$ & $0.067 \mu \mathrm{g}$ & {$[58]$} \\
\hline thin layer chromatography & $\begin{array}{l}\text { standard single-lens reflex } \\
\text { camera Nikon D3100 } \\
\text { (Nikon, Tokyo, Japan) with } \\
\text { CMOS chip of APS-C size }\end{array}$ & $\begin{array}{l}\text { alcohol extract of } \\
\text { Galium verum }\end{array}$ & $\begin{array}{l}\text { fingerprints of individual } \\
\text { extracts were described }\end{array}$ & {$[59]$} \\
\hline $\begin{array}{l}\text { colorimetric assay of } \\
\text { butyrylcholinesterase } \\
\text { activity on small cut of filter } \\
\text { paper, indoxylacetate served } \\
\text { as a chromogenic substrate }\end{array}$ & $\begin{array}{l}\text { smartphone Samsung } \\
\text { Galaxy S5 camera } \\
\text { (Samsung, Seoul, South } \\
\text { Korea) }\end{array}$ & butyrylcholinesterase & $\begin{array}{l}3.09 \times 10^{-6} \mathrm{~kat} / \mathrm{ml} \text { when } \\
\mathrm{R} \text { channel used for the } \\
\text { assay }\end{array}$ & {$[65]$} \\
\hline $\begin{array}{l}\text { assay performed in bubble } \\
\text { wraps containing glucose } \\
\text { oxidase and peroxidase, } \\
\text { color end products from } \\
\text { o-phenylenediamine were } \\
\text { formed }\end{array}$ & $\begin{array}{l}\text { camera integrated into } \\
\text { smartphone Sony Xperia } \\
\text { MT27i (Sony, Tokyo, Japan) }\end{array}$ & glucose (glycemia) & $0.75 \mathrm{mmol} / \mathrm{l}$ & {$[66]$} \\
\hline $\begin{array}{l}\text { assay performed in } \\
\text { microtubes, phenolphthalein } \\
\text { in alkaline medium was } \\
\text { added to samples }\end{array}$ & $\begin{array}{l}\text { an unspecified smartphone } \\
\text { camera }\end{array}$ & $\begin{array}{l}\text { ethanol in alcoholic } \\
\text { beverages }\end{array}$ & $2.1 \%(v / v)$ & {$[67]$} \\
\hline $\begin{array}{l}\text { colorimetric assay of lipase } \\
\text { activity on small cut of filter } \\
\text { paper, indoxylacetate served } \\
\text { as a chromogenic substrate, } \\
\text { the reaction was stopped in } \\
\text { the presence of carbofuran }\end{array}$ & $\begin{array}{l}\text { smartphone Samsung } \\
\text { Galaxy S5 camera } \\
\text { (Samsung, Seoul, South } \\
\text { Korea) }\end{array}$ & carbofuran & $\begin{array}{l}37.2 \mathrm{nmol} / \text { for a sample } \\
5 \mu \mathrm{l}\end{array}$ & {$[70]$} \\
\hline
\end{tabular}

with a digital output can be learned from the following examples. Streptomycin was, for instance, detected by colorimetry with a smartphone as the output [79]. The assay worked on the principle of interaction between an aptamer and streptomycin, the excess aptamer hybridized with complementary DNA and the resulting double stranded DNA interacted with green fluorescence providing the color SYBR Green I. The assay exerted a linear range of $0.1-100 \mu \mathrm{mol} / \mathrm{l}$ and a limit of detection of $94 \mathrm{nmol} / \mathrm{l}$. An immunosensor with digital output was constructed for the measurement of alkaline phosphatase which was intended to serve in milk quality control [80]. The assay was based on alkaline phosphatase separation from a sample on paper modified with anti-alkaline phosphatase antibodies. After separation, alkaline phosphatase converts chromogenic substrate 5-bromo-4-chloro 3-indolyl phosphate, providing blue-green coloration which was observable via a smartphone camera. The assay had a two-order sized linear response from 10 to1,000 U/ $\mathrm{ml}$ and exerted a limit of detection of $0.87 \mathrm{U} / \mathrm{ml}$. Another assay on alkaline phosphatase was performed by $\mathrm{Yu}$ and coworkers [81]. In this assay, the paper strip contained gold nanoparticles modified with phosphotyrosine and a testing line with antibodies specific to phosphotyrosine. Alkaline phosphatase from a sample causes the dephosphorylation of nanoparticles and affects the interaction between nanoparticles and immobilized antibodies. The colored spots were recorded and analyzed by a smartphone. The assay exerted a dynamic range of $0.1-150 \mathrm{U} / 1$ and a limit of detection of $0.1 \mathrm{U} / 1$. Immunoassays have good specifications to reveal sized analytes because the preparation of antibodies against sized antigens is easier and the sized antigens can be precipitated by antibodies because more immunoglobulins can bind to one sized structure like cells and large proteins. The precipitation is conditioned by fact that immunoglobulins have more paratopes binding antigen. It can be from two (e.g. immunoglobulin G - one subunit with two paratopes) up to ten (e.g. immunoglobulin $\mathrm{M}$ - five subunit, each two paratopes). The detection of the bacterium Escherichia coli was described in the paper by Sai and coworkers [82]. The assay worked on the principle of a paper with an antibody capturing $E$. coli from samples and the captured bacterium was then labelled with gold nanoparticles modified with another anti E. coli antibody. 
Formed spots can be further highlighted by the addition of silver ions which are reduced by gold nanoparticles to metallic silver. The assay was performed on standard filter papers and a cell phone camera (no further specification provided in the paper) served for image processing. The limit of detection for the assay was equal to $57 \mathrm{CFU} / \mathrm{ml}$. This result is quite close to the standard ELISA method for bacteria detection [83], therefore the digital camera assay could substitute the ELISA.

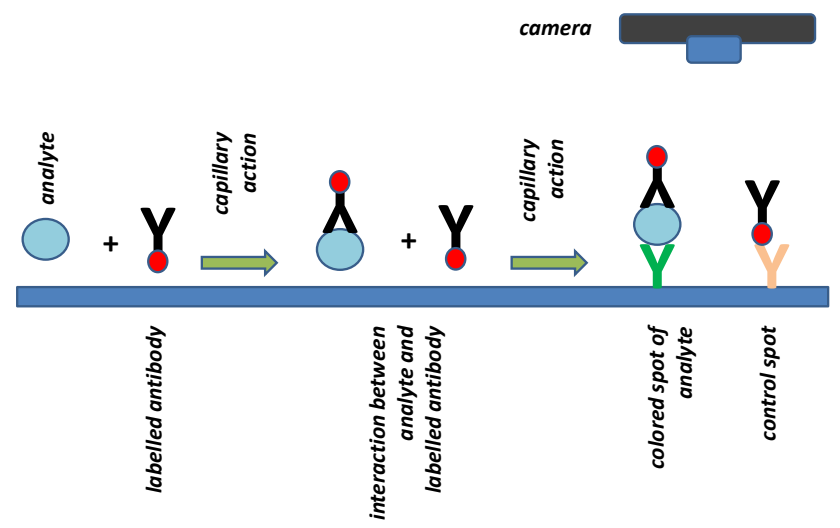

Figure 4 General principle of lateral flow immunoassay with digital camera on the output.

Colorimetric immunoassays with signal scoring by a naked eye can be easily improved by the addition of a digital camera as the output. Lateral flow immunoassays also known as lateral flow tests are designed as standard hand-held methods and the formed spots can be characterized by the digital camera. In principle, the lateral flow immunoassay consists of sample migration by capillary action up to the spot where it is captured by an immobilized antibody, another labelled (fluorescent nanoparticle, fluorescent dye etc) antibody finalizes the formed sandwich and it causes that the spot is visible due to coloration [20, 84-88]. The control zone is represented by an antibody against the labelled antibody. The control zone should be formed in any case regardless of the presence of analyte in the sample. As an alternative, the assay can also be performed on the principle of single stranded sequences of DNA hybridization and such a method can also be combined with a digital camera [57, 89-91]. Single nucleotide polymorphism can be scrutinized by the digital camera based lateral flow immunoassay [92-96]. Such devices are an alternative to a standard lateral flow immunoassay.

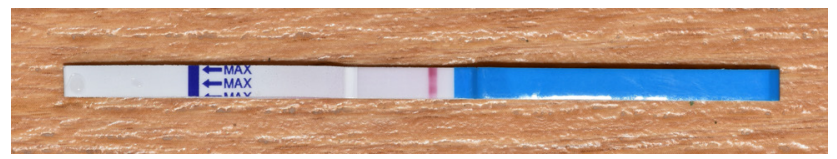

Figure 5 Example of a commercially available lateral flow immunoassay strip - human chorionic gonadotropin test.
The efficacy of an assay where a digital camera is combined with a lateral flow immunoassay is expected to be higher than the lateral flow immunoassay alone [97, 98]. A general principle of a lateral flow immunoassay in combination with a digital camera is depicted as figure 4. An example of a commercially available lateral flow immunoassay test strip (human chorionic gonadotropin test) is in figure 5. The relevance of the combination can be learned from following examples. Lateral flow immunoassay was for instance chosen as a method for the detection of cocaine [99]. In the cited paper, a magnetic lateral flow immunoassay was performed on urine samples for the presence of cocaine. The assay worked on the principle of competition between cocaine and conjugate cocaine - bovine albumin. Magnetic beads covered with anti-cocaine antibodies reacted with cocaine or complex cocaine - the bovine albumin formed a gray line on the support pad. Standard smartphone camera served for signal scaling. The assay had limit of detection $3 \mathrm{nmol} / \mathrm{l}$ and linear range $5-500 \mathrm{ng} / \mathrm{ml}$. A lateral flow immunoassay with a digital camera as the output was introduced by Xia and coworkers for chloramphenicol residue assay [100]. The assay exerted limit of detection $0.03 \mathrm{ng} / \mathrm{ml}$. A smart phone Samsung Galaxy S7 Edge with a digital camera and lateral flow immunoassay together were performed for albumin assay [101]. The assay had a limit of detection of $1.71 \mathrm{pg} / \mathrm{ml}$ and limit of quantification $26.48 \mathrm{pg} / \mathrm{ml}$. In another experiment, digoxigenin was assayed by lateral flow chromatography [102]. Digoxigenin is a toxic plant steroid forming conjugates to sugars and known for immunogenicity. The assay was mediated by CMOS camera from smartphone iPhone 5S (Apple, Cupertino, California, USA) and used an antibody - gold nanoparticles. The best limit of detection was $14.4 \mathrm{nmol} / \mathrm{l}$ and the limit of quantification $19.1 \mathrm{nmol} / \mathrm{l}$. The assay by smartphone was compared with a professional digital colorimeter BioImager (ChemStudio Plus, Analytic Jena, Jena, Germany). When the two assays compared, the professional colorimeter proved to have better specifications (sensitivity, limits of detection and quantification) but the advantages were not significant and considering price and simplicity, make the smartphone camera a viable competitor to the standard colorimetry. A lateral flow immunoassay improved by signal measuring by a smartphone camera was also performed for the determination of 8-Hydroxy-2'Deoxyguanosine [103] and the identification of antibiotic resistance with the combination of a lateral flow assay, polymerase chain reaction and a smartphone [104]. An overview of the aforementioned immunoassays is given in table 2 . 
Table 2 Immunoassays with digital camera on the output

\begin{tabular}{|c|c|c|c|c|}
\hline Assay method & Used camera & Analyte & $\begin{array}{l}\text { Limit of detection res- } \\
\text { pective further specifi- } \\
\text { cations }\end{array}$ & References \\
\hline $\begin{array}{l}\text { an aptamer interacted } \\
\text { with streptomycin, the } \\
\text { excess aptamer reacted } \\
\text { with complementary } \\
\text { DNA and then SYBR } \\
\text { Green I providing green } \\
\text { fluorescence }\end{array}$ & $\begin{array}{l}\text { an unspecified } \\
\text { smartphone camera }\end{array}$ & streptomycin & $\begin{array}{l}\text { linear range } 0.1-100 \\
\mu \mathrm{mol} / \mathrm{l} \text { and limit of } \\
\text { detection } 94 \mathrm{nmol} / \mathrm{l}\end{array}$ & [79] \\
\hline $\begin{array}{l}\text { alkaline phosphatase } \\
\text { was separated on papers } \\
\text { modified with specific } \\
\text { antibodies; in the second } \\
\text { step, } 5 \text {-bromo-4-chloro } \\
\text { 3-indolyl phosphate } \\
\text { provided blue-green } \\
\text { coloration due to the } \\
\text { enzyme activity }\end{array}$ & $\begin{array}{l}\text { an unspecified } \\
\text { smartphone camera }\end{array}$ & alkaline phosphatase & $\begin{array}{l}\text { linear response from } 10 \\
\text { to } 1,000 \mathrm{U} / \mathrm{ml} \text {, limit of } \\
\text { detection } 0.87 \mathrm{U} / \mathrm{ml}\end{array}$ & {$[80]$} \\
\hline $\begin{array}{l}\text { strip containing gold } \\
\text { nanoparticles modified } \\
\text { with phosphotyrosine } \\
\text { and testing line with } \\
\text { antibodies specific } \\
\text { to phosphotyrosine; } \\
\text { alkaline phosphatase } \\
\text { from a sample caused } \\
\text { dephosphorylation and } \\
\text { affecte the interaction } \\
\text { between nanoparticles } \\
\text { and antibodies }\end{array}$ & $\begin{array}{l}\text { an unspecified } \\
\text { smartphone camera }\end{array}$ & alkaline phosphatase & $\begin{array}{l}\text { dynamic range } 0.1-150 \\
\mathrm{U} / \mathrm{I} \text { and limit of detection } \\
0.1 \mathrm{U} / \mathrm{l}\end{array}$ & {$[81]$} \\
\hline $\begin{array}{l}\text { paper with antibodies } \\
\text { against Escherichia coli } \\
\text { captured the bacterium, } \\
\text { gold nanoparticles with } \\
\text { antibodies labelled } \\
\text { captured bacterium, } \\
\text { reduction of silver ions } \\
\text { make the spots more } \\
\text { visible }\end{array}$ & $\begin{array}{l}\text { an unspecified cell phone } \\
\text { camera }\end{array}$ & E. coli & $\begin{array}{l}\text { limit of detection } 57 \\
\text { CFU } / \mathrm{ml}\end{array}$ & {$[82]$} \\
\hline lateral flow immunoassay & $\begin{array}{l}\text { an unspecified } \\
\text { smartphone camera }\end{array}$ & cocaine & $\begin{array}{l}\text { limit of detection } 3 \\
\mathrm{nmol} / \mathrm{l} \text {, linear range } 5- \\
500 \mathrm{ng} / \mathrm{ml}\end{array}$ & [99] \\
\hline lateral flow immunoassay & $\begin{array}{l}\text { an unspecified digital } \\
\text { camera }\end{array}$ & chloramphenicol & $\begin{array}{l}\text { limit of detection } 0.03 \\
\mathrm{ng} / \mathrm{ml}\end{array}$ & {$[100]$} \\
\hline lateral flow immunoassay & $\begin{array}{l}\text { smartphone camera } \\
\text { Samsung Galaxy S7 Edge } \\
\text { (Samsung, Seoul, South } \\
\text { Korea) }\end{array}$ & albumin & $\begin{array}{l}\text { limit of detection } \\
1.71 \mathrm{pg} / \mathrm{ml} \text {, limit of } \\
\text { quantification } 26.48 \\
\mathrm{pg} / \mathrm{ml}\end{array}$ & [101] \\
\hline lateral flow immunoassay & $\begin{array}{l}\text { smartphone camera } \\
\text { iPhone 5S (Apple, } \\
\text { Cupertino, Ca, USA) }\end{array}$ & digoxigenin & $\begin{array}{l}\text { limit of detection } \\
14.4 \mathrm{nmol} / \mathrm{l} \text {, limit of } \\
\text { quantification } 19.1 \\
\mathrm{nmol} / \mathrm{l}\end{array}$ & {$[102]$} \\
\hline
\end{tabular}




\section{Conclusions}

Digital camera based analytical devices appear to be promising for current praxis and would meet demands from various laboratories including clinical, control of manufacturing processes, assay of pollutants, hygienic control etc. It is not expected that camera based handheld assays will replace standard instrumental methods like chromatography and mass spectrometry but they represent a support to the standard devices and can replace them under some specific conditions like field assay or assays performed under emergency conditions. The major advantage of the hand-held assays with digital cameras is the overall simplicity, low price and general availability. An increasing role of hand-held assays with digital cameras is expected in the next few years. Further development of analytical methods based on digital camera can also be accelerated by other techniques like 3D printing [105-107]. The combination of smartphone camera and individually manufactured parts by 3D printing technique would make analytical techniques available for nearly everyone.

\section{Acknowledgements}

A long-term organization development plan "Medical Aspects of Weapons of Mass Destruction" and Specific research funds (Faculty of Military Health Sciences, University of Defense, Czech Republic) and TACR TH03030336 (Technological Agency of the Czech Republic) are gratefully acknowledged.

\section{References}

[1] Allen DR, McWhinney BC. Quadrupole Time-of-Flight Mass Spectrometry: A Paradigm Shift in Toxicology Screening Applications. Clin Biochem Rev. 2019;40:135-46.

[2] Anderson HE, Santos IC, Hildenbrand ZL, Schug KA. A review of the analytical methods used for beer ingredient and finished product analysis and quality control. Anal Chim Acta. 2019;28:1-20.

[3] Stachniuk A, Sumara A, Montowska M, Fornal E. Liquid chromatography-mass spectrometry bottom-up proteomic methods in animal species analysis of processed meat for food authentication and the detection of adulterations. Mass Spectrom Rev. 2019;9:21605.

[4] Tang Y, Zhang JL. Recent developments in DNA adduct analysis using liquid chromatography coupled with mass spectrometry. J Sep Sci. 2019;43:31-55.

[5] Temporini C, Colombo R, Calleri E, Tengattini S, Rinaldi F, Massolini G. Chromatographic tools for plant-derived recombinant antibodies purification and characterization. J Pharm Biomed Anal. 2019;14:112920.

[6] Ferre S, Gonzalez-Ruiz V, Guillarme D, Rudaz S. Analytical strategies for the determination of amino acids: Past, present and future trends. J Chromatogr B Analyt Technol Biomed Life Sci. 2019;22:121819.

[7] Conti C, Guarino M, Bacenetti J. Measurements techniques and models to assess odor annoyance: A review. Environ Int. 2019;134:105261.

[8] Budau M, Hancu G, Rusu A, Muntean DL. Analytical methodologies for the enantiodetermination of citalopram and its metabolites. Chirality. 2019;8:23139.

[9] Alsaleh M, Barbera TA, Andrews RH, Sithithaworn P, Khuntikeo $\mathrm{N}$, Loilome W, et al. Mass Spectrometry: A Guide for the Clinician. J Clin Exp Hepatol. 2019;9:597-606.

[10] Knikman JE, Rosing H, Guchelaar HJ, Cats A, Beijnen JH. A review of the bioanalytical methods for the quantitative determination of capecitabine and its metabolites in biological matrices. Biomed Chromatogr. 2020;34:e4732.

[11] Liu HY, Hopping GC, Vaidyanathan U, Ronquillo YC, Hoopes PC, Moshirfar M. Polymerase Chain Reaction and Its Application in the Diagnosis of Infectious Keratitis. Med Hypothesis Discov Innov Ophthalmol. 2019;8:152-5.

[12] Zidovec Lepej S, Poljak M. Portable molecular diagnostic instruments in microbiology: current status. Clin Microbiol Infect. 2019;28:30502-6.

[13] Bissonnette L, Bergeron MG. Portable devices and mobile instruments for infectious diseases point-of-care testing. Expert Rev Mol Diagn. 2017;17:471-94.

[14] Gao Z, Liu Y, Wang X, Wei X, Han J, Mini-Barcoding DN. A Derived Barcoding Method for Herbal Molecular Identification. Front. Plant Sci. 2019;10:984.

[15] Parveen I, Gafner S, Techen N, Murch SJ, Khan IA. DNA Barcoding for the Identification of Botanicals in Herbal Medicine and Dietary Supplements: strengths and Limitations. Planta Med. 2016;82:1225-35.

[16] Cao L, Cui X, Hu J, Li Z, Choi JR, Yang Q, et al. Advances in digital polymerase chain reaction (dPCR) and its emerging biomedical applications. Biosens Bioelectron. 2017;90:459-74.

[17] Parson W. Age Estimation with DNA: From Forensic DNA Fingerprinting to Forensic (Epi)Genomics: A Mini-Review. Gerontology. 2018;64:326-32.

[18] J. Kruger, D. Schleinitz, Genetic Fingerprinting Using Microsatellite Markers in a Multiplex PCR Reaction: A Compilation of Methodological Approaches from Primer Design to Detection Systems, Methods Mol. Biol., 2017;1492:1-15.

[19] Iha K, Inada M, Kawada N, Nakaishi K, Watabe S, Tan YH, et al. Ultrasensitive ELISA Developed for Diagnosis. Diagnostics (Basel). 2019;9:78.

[20] Gao Y, Huang X, Zhu Y, Lv Z. A brief review of monoclonal antibody technology and its representative applications in immunoassays. J Immunoassay Immunochem. 2018;39:351-64.

[21] Pohanka M. Monoclonal and polyclonal antibodies production - preparation of potent biorecognition element. J Appl Biomed. 2009;7:115-21.

[22] Grange RD, Thompson JP, Lambert DG. Radioimmunoassay, enzyme and non-enzyme-based immunoassays. $\mathrm{Br} J$ Anaesth. 2014;112:213-6. 
[23] Meriggioli MN. Use of immunoassays in neurological diagnosis and research. Neurol Res. 2005;27:734-40.

[24] Betterle C, Coco G, Zanchetta R. Adrenal cortex autoantibodies in subjects with normal adrenal function. Best Pract Res Clin Endocrinol Metab. 2005;19:85-99.

[25] Villain M, Cirimele V, Kintz P. Hair analysis in toxicology. Clin Chem Lab Med. 2004;42:1265-72.

[26] Pohanka M. Small camera as a handheld colorimetric tool in the analytical chemistry. Chem Pap. 2017;71:1553-61.

[27] Chary RV, Lakshmi DR, Sunitha KV. Feature Extraction Methods for Color Image Similarity, Advanced Computing. Int J. 2012;3:147-57.

[28] Oberholzer M, Ostreicher M, Christen H, Bruhlmann M. Methods in quantitative image analysis. Histochem Cell Biol. 1996;105:333-55.

[29] Gillespy T, Richardson ML, Rowberg AH. Displaying radiologic images on personal computers: practical applications and uses. J Digit Imaging. 1994;7:101-6.

[30] Hameed FS, Alwan HM, Ateia QA. Pose Estimation of Objects Using Digital Image Processing for Pick-and-Place Applications of Robotic Arms. Engineering and Technology Journal. 2020;38:707-18.

[31] Roda A, Michelini E, Cevenini L, Calabria D, Calabretta MM, Simoni P. Integrating Biochemiluminescence Detection on Smartphones: Mobile Chemistry Platform for Point-of-Need Analysis. Anal Chem. 2014;86:7299-304.

[32] Garcia A, Erenas MM, Marinetto ED, Abad CA, de Orbe-Paya I, Palma AJ, et al. Mobile phone platform as portable chemical analyzer, Sens. Actuator B-Chem. 2011;156:350-9.

[33] Wei QS, Nagi R, Sadeghi K, Feng S, Yan E, Ki SJ, et al. Detection and Spatial Mapping of Mercury Contamination in Water Samples Using a Smart-Phone. ACS Nano. 2014;8:1121-9.

[34] Sanders JE, Goldstein BS, Leotta DF, Richards KA. Image processing techniques for quantitative analysis of skin structures. Comput Methods Programs Biomed. 1999;59:167-80.

[35] Hong JH, Kim DH, Rhyu IJ, Kye YC, Ahn HH. A simple morphometric analysis method for dermal microstructure using color thresholding and moments. Skin Res Technol. 2019;20:12776.

[36] Sarhan A, Rokne J, Alhajj R. Glaucoma detection using image processing techniques: A literature review. Comput Med Imaging Graph. 2019;78:101657.

[37] Al-Akhras M, Barakat A, Alawairdhi M, Habib M. Using soft computing techniques to diagnose Glaucoma disease. J Infect Public Health. 2019;24:30305-3.

[38] Green MV, Pengo T, Raybuck JD, Naqvi T, McMullan HM, Hawkinson JE, et al. Automated Live-Cell Imaging of Synapses in Rat and Human Neuronal Cultures. Front Cell Neurosci. 2019;13:467.

[39] Wang W, Cai L. Inclusion extraction from diamond clarity images based on the analysis of diamond optical properties. Opt Express. 2019;27:27242-55.

[40] Bueno G, Fernandez-Carrobles MM, Deniz O, Garcia-Rojo M. New Trends of Emerging Technologies in Digital Pathology. Pathobiology. 2016;83:61-9.

[41] Longfils M, Smisdom N, Ameloot M, Rudemo M, Lemmens V, Fernandez GS, et al. Raster Image Correlation Spectroscopy Performance Evaluation. Biophys J. 2019;10:30852-5.
[42] Sabanci K. Detection of Sunn Pest Damaged Wheat Grains Using Artificial Bee Colony Optimization Based Artificial Intelligence Techniques. J Sci Food Agric. 2019;23:10093.

[43] Sabanci K, Kayabasi A, Toktas A. Computer vision-based method for classification of wheat grains using artificial neural network. J Sci Food Agric. 2017;97:2588-93.

[44] Luo J, Zhou RG, Luo GF, Li YC, Liu GZ. Traceable Quantum Steganography Scheme Based on Pixel Value Differencing. Sci Rep. 2019;9:15134.

[45] Sabri S, Richelme F, Pierres A, Benoliel AM, Bongrand P. Interest of image processing in cell biology and immunology. J Immunol Methods. 1997;208:1-27.

[46] Roeder AH, Cunha A, Burl MC, Meyerowitz EM. A computational image analysis glossary for biologists. Development. 2012;139:3071-80.

[47] Kato K, Hayashi S. Practical guide of live imaging for developmental biologists. Dev Growth Differ. 2008;50:381-90.

[48] Cavey M, Lecuit T. Imaging cellular and molecular dynamics in live embryos using fluorescent proteins. Methods Mol Biol. 2008;420:219-38.

[49] Manandhar S, Bouthemy P, Welf E, Danuser G, Roudot P. C. Kervrann, 3D Flow Field Estimation and Assessment for Live Cell Fluorescence Microscopy. Bioinformatics. 2020;36:1317-25.

[50] Sarc R, Curtis A, Kandlbauer L, Khodier K, Lorber KE, Pomberger $R$. Digitalisation and intelligent robotics in value chain of circular economy oriented waste management - A review. Waste Manag. 2019;95:476-92.

[51] Blasco J, Munera S, Aleixos N, Cubero S, Molto E. Machine Vision-Based Measurement Systems for Fruit and Vegetable Quality Control in Postharvest. Adv Biochem Eng Biotechnol. 2017;161:71-91.

[52] Li J, Sun Y], Chen C, Sheng T, Liu P, Zhang GB. A smartphoneassisted microfluidic chemistry analyzer using image-based colorimetric assays for multi-index monitoring of diabetes and hyperlipidemia. Anal Chim Acta. 2019;1052:105-12.

[53] Qi P, Wang G, Gao Z, Liu X, Liu W. Measurements of Temperature Distribution for High Temperature Steel Plates Based on Digital Image Correlation. Materials (Basel). 2019;12:3322.

[54] Chiu SH, Urban PL. Fusion of microlitre water-in-oil droplets for simple, fast and green chemical assays. Analyst (Lond). 2015;140:5145-51.

[55] Topakova AA, Salmin VV, Gar'kavenko VV, Levchenko JS, Lazarenko VI. Development of optoelectronic hardware program complex for the analysis of hypoxia in the anterior eye camera in persons wearing contact lenses, in: E.A. Genina, V.L. Derbov, D.E. Postnov, A.B. Pravdin, K.V. Larin, I.V. Meglinski, V.V. Tuchin (Eds.) Saratov Fall Meeting 2015 Third International Symposium on Optics and Biophotonics; and Seventh FinnishRussian Photonics and Laser Symposium, Spie-Int Soc Optical Engineering, Bellingham, 2016.

[56] Prasad A, Hasan SM, Grouchy S, Gartia MR. DNA microarray analysis using a smartphone to detect the BRCA-1 gene. Analyst (Lond). 2019;144:197-205.

[57] Kalligosfyri PM, Sevastou A, Kyriakou IK, Tragoulias SS, Kalogianni DP, Christopoulos TK. Smartphone-based chemiluminometric hybridization assays and quantitative competitive polymerase chain reaction. Anal Chim Acta. 2019;11:123-30.

[58] Tie-xin T, Hong W. An Image Analysis System for Thin-Layer Chromatography Quantification and Its Validation. J Chromatogr Sci. 2008;46:560-4. 
[59] Simion M, Cobzac SC, Casoni D. Image analysis approaches to improve the thin layer chromatography - chemometric based investigations of natural extracts. Stud Univ Babes-Bolyai Chem. 2017;62:67-80.

[60] Sinhababu A, Basu S, Dey H. Modified ninhydrin reagents to detect amino acids on TLC plates. Res Chem Intermed. 2015;41:2785-92.

[61] Kerr E, West C, Hartwell SK. Quantitative TLC-Image Analysis of Urinary Creatinine Using lodine Staining and RGB Values. I Chromatogr Sci. 2016;54:639-46.

[62] Hemmateenejad B, Farzam SF, Mobaraki N. Simultaneous measurement of leucine and isoleucine by multivariate image analysis-thin layer chromatography (MIA-TLC). J. Iran Chem. Soc. 2014;11:1609-17.

[63] Kim Y, Choi SW. The preliminary evaluation of semi-quantitative analysis by in situ pre-chromatographic derivatization of amines and image analysis in TLC. Anal Sci Technol. 2015;28:79-85.

[64] Nishigaki A, Shoji T, Ohkubo K, Saito N. Development of a simple, sensitive and rapid quantitative method for polycyclic aromatic hydrocarbons in environmental samples by thin-layer chromatography and a digital camera. Bunseki Kagaku. 2012;61:939-46.

[65] Pohanka M. Photography by Cameras Integrated in Smartphones as a Tool for Analytical Chemistry Represented by an Butyrylcholinesterase Activity Assay. Sensors (Basel). 2015;15:13752-62.

[66] Martinkova P, Pohanka M. Colorimetric sensor based on bubble wrap and camera phone for glucose determination. J Appl Biomed. 2016;14:315-9.

[67] Marinho OR, Lima MJ, Rocha FR, Reis BF, Kamogawa MY. A greener, fast, and cost-effective smartphone-based digital image procedure for quantification of ethanol in distilled beverages. Microchem J. 2019;147:437-43.

[68] Pohanka M. Antidotes Against Methanol Poisoning: A Review. Mini Rev Med Chem. 2019;19:1126-33.

[69] Pohanka M. Toxicology and the biological role of methanol and ethanol: current view, Biomed. Pap-Olomouc. 2016;160:54-63.

[70] Pohanka M, Zakova J, Sedlacek I. Digital camera-based lipase biosensor for the determination of paraoxon, Sens. Actuat. Biol Chem. 2018;273:610-5.

[71] Ibau C, Md Arshad MK, Gopinath SC. Current advances and future visions on bioelectronic immunosensing for prostatespecific antigen. Biosens Bioelectron. 2017;98:267-84.

[72] Hosu 0, Selvolini G, Cristea C, Marrazza G. Electrochemical Immunosensors for Disease Detection and Diagnosis. Curr Med Chem. 2018;25:4119-37.

[73] Zhang H, Miller BL. Immunosensor-based label-free and multiplex detection of influenza viruses: state of the art. Biosens Bioelectron. 2019;141:25.

[74] Eivazzadeh-Keihan R, Pashazadeh-Panahi P, Mahmoudi T, Chenab KK. Baradaran, Hashemzaei B, Radinekiyan F, Mokhtarzadeh A, Maleki A. Dengue virus: a review on advances in detection and trends - from conventional methods to novel biosensors. Mikrochim Acta. 2019;186:329.

[75] Pollap A, Kochana J. Electrochemical Immunosensors for Antibiotic Detection. Biosensors (Basel). 2019;9:61.

[76] Zhou J, Qi Q, Wang C, Qian Y, Liu G, Wang Y, et al. Surface plasmon resonance (SPR) biosensors for food allergen detection in food matrices. Biosens Bioelectron. 2019;142:21.
[77] Pasinszki T, Krebsz M. Advances in celiac disease testing. Adv Clin Chem. 2019;91:1-29.

[78] Pohanka M, Skladal P. Serological diagnosis of tularemia in mice using the amperometric immunosensor. Electroanalysis. 2007;19:2507-12.

[79] Lin B, Yu Y, Cao Y, Guo M, Zhu D, Dai J, et al. Point-of-care testing for streptomycin based on aptamer recognizing and digital image colorimetry by smartphone. Biosens Bioelectron. 2018;100:482-9.

[80] Mahato K, Chandra P. Paper-based miniaturized immunosensor for naked eye ALP detection based on digital image colorimetry integrated with smartphone. Biosens Bioelectron. 2019;128:9-16.

[81] Yu L, Shi Z, Fang C, Zhang Y, Liu Y, Li C. Disposable lateral flow-through strip for smartphone-camera to quantitatively detect alkaline phosphatase activity in milk. Biosens Bioelectron. 2015;69:307-15.

[82] Ma S, Tang YY, Liu JQ, Wu JM. Visible paper chip immunoassay for rapid determination of bacteria in water distribution system. Talanta. 2014;120:135-40.

[83] Pohanka M, Pavlis O, Kroca M. ELISA detection of Francisella tularensis using polyclonal and monoclonal antibodies. Def Sci J. 2008;58:698-702.

[84] Gasperino D, Baughman T, Hsieh HV, Bell D, Weigl BH. Improving Lateral Flow Assay Performance Using Computational Modeling. Annu Rev Anal Chem (Palo Alto, Calif). 2018;11:219-44.

[85] Anfossi L, Di Nardo F, Cavalera S, Giovannoli C, Baggiani C. Multiplex Lateral Flow Immunoassay: An Overview of Strategies towards High-throughput Point-of-Need Testing. Biosensors (Basel). 2018;9:2.

[86] Urusov AE, Zherdev AV, Dzantiev BB. Towards Lateral Flow Quantitative Assays: detection Approaches. Biosensors (Basel). 2019;9:89.

[87] Hsieh HV, Dantzler JL, Weigl BH. Analytical Tools to Improve Optimization Procedures for Lateral Flow Assays. Diagnostics (Basel). 2017;7:29.

[88] Wang Z, Zhi D, Zhao Y, Zhang H, Wang X, Ru Y, et al. Lateral flow test strip based on colloidal selenium immunoassay for rapid detection of melamine in milk, milk powder, and animal feed. Int J Nanomedicine. 2014;9:1699-707.

[89] Magiati M, Sevastou A, Kalogianni DP. A fluorometric lateral flow assay for visual detection of nucleic acids using a digital camera readout. Mikrochim Acta. 2018;185:314.

[90] Paterson AS, Raja B, Mandadi V, Townsend B, Lee M, Buell A, et al. A low-cost smartphone-based platform for highly sensitive point-of-care testing with persistent luminescent phosphors. Lab Chip. 2017;17:1051-9.

[91] Jahanpeyma F, Forouzandeh M, Rasaee MJ, Shoaie N. An enzymatic paper-based biosensor for ultrasensitive detection of DNA. Front Biosci. 2019;11:122-35.

[92] Spyrou EM, Kalogianni DP, Tragoulias SS, Ioannou PC, Christopoulos TK. Digital camera and smartphone as detectors in paper-based chemiluminometric genotyping of single nucleotide polymorphisms. Anal Bioanal Chem. 2016;408:7393-402.

[93] Greulich T, Rodriguez-Frias F, Belmonte I, Klemmer A, Vogelmeier CF, Miravitlles M. Real world evaluation of a novel lateral flow assay (AlphaKit(R) QuickScreen) for the detection of alpha-1-antitrypsin deficiency. Respir Res. 2018;19:151. 
[94] Lin CW, Kuo JC, Liu HL, Cheng YS, Huang HL. A new method for detection of single nucleotide polymorphism in a female reproduction-associated gene, tmigd1, of Anas platyrhynchos using a strip biosensor with gold nanoparticles. Poult Sci. 2018;97:3456-62.

[95] Xuhong Y, Sinong Z, Jianping L, Yu C, Juanli Z, Chao Z, et al. A PCR-lateral flow assay system based on gold magnetic nanoparticles for CYP2C19 genotyping and its clinical applications. Artif Cells Nanomed Biotechnol. 2019;47:636-43.

[96] Gomez-Martinez J, Silvy M, Chiaroni J, Fournier-Wirth C, Roubinet F, Bailly P, et al. Multiplex Lateral Flow Assay for Rapid Visual Blood Group Genotyping. Anal Chem. 2018;90:7502-9.

[97] Hou Y, Wang K, Xiao K, Qin W, Lu W, Tao W, et al. SmartphoneBased Dual-Modality Imaging System for Quantitative Detection of Color or Fluorescent Lateral Flow Immunochromatographic Strips. Nanoscale Res Lett. 2017;12:291.

[98] Venkatraman V, Steckl AJ. Integrated OLED as excitation light source in fluorescent lateral flow immunoassays. Biosens Bioelectron. 2015;74:150-5.

[99] Wu J, Dong M, Zhang C, Wang Y, Xie M, Chen Y. Magnetic Lateral Flow Strip for the Detection of Cocaine in Urine by Naked Eyes and Smart Phone Camera. Sensors (Basel). 2017;17:1286.

[100] Xia X, Xu Y, Ke R, Zhang H, Zou M, Yang W, et al. A highly sensitive europium nanoparticle-based lateral flow immunoassay for detection of chloramphenicol residue. Anal Bioanal Chem. 2013;405:7541-4.
[101] Foysal KH, Seo SE, Kim MJ, Kwon OS, Chong JW. Analyte Quantity Detection from Lateral Flow Assay Using a Smartphone. Sensors (Basel). 2019;19:4812.

[102] Ruppert C, Phogat N, Laufer S, Kohl M, Deigner HP. A smartphone readout system for gold nanoparticle-based lateral flow assays: application to monitoring of digoxigenin. Mikrochim Acta. 2019;186:119.

[103] Hainsworth DP, Gangula A, Ghoshdastidar S, Kannan R, Upendran A. Diabetic Retinopathy Screening Using a Gold Nanoparticle-Based Paper Strip Assay for the At-Home Detection of the Urinary Biomarker, 8-Hydroxy-2 '-Deoxyguanosine. Am J Ophthalmol. 2020;213:306-19.

[104] Rajendran VK, Bakthavathsalam P, Bergquist PL, Sunna A. Smartphone detection of antibiotic resistance using convective PCR and a lateral flow assay. Sens Actuators B Chem. 2019;298:126849

[105] Roda A, Guardigli M, Calabria D, Calabretta MM, Cevenini L, Michelini E. A 3D-printed device for a smartphone-based chemiluminescence biosensor for lactate in oral fluid and sweat. Analyst (Lond). 2014;139:6494-501.

[106] Rogers Cl, Qaderi K, Woolley AT. G.P. Nordin, 3D printed microfluidic devices with integrated valves. Biomicrofluidics. 2015;9:016501.

[107] Pohanka M. Three-Dimensional Printing in Analytical Chemistry: principles and Applications. Anal Lett. 2016;49:2865-82. 